\title{
External and Internal Factors Affecting Subjective Well Being Parents of Children With Special Needs
}

\author{
Sri Asih Andayani1 ${ }^{1},{ }^{*}$, Jatie K. Pudjibudojo ${ }^{2}$, Evy Tjahjono ${ }^{3}$ \\ 1, 2, 3 Psychology, Universitas Surabaya, Surabaya, Indonesia. \\ *Corresponding author. Email: yaniyosinaga88@gmail.com
}

\begin{abstract}
Subjective well-being (SWB) is a key to a prosperous life. All married couples expect to deliver physicallynormal babies. Unfortunately, some families have special need children. In general, the number SWB parents of children with special needs are lower than SWB parents with typical children. Factors affecting SWB parents of children with special needs need to be determined in order to help develop proper strategies to increase the SWB of these factors. This study analyzed the external and internal SWB factors among parents of children with special needs. This Systematic Literature Review (SLR) showed that the internal SWB factors in parents of children with special needs included hope, gratitude, spiritual, emotional control, parenting self-efficacy, resilience, marital status, self-efficacy, mindful parenting, parental assessment and self-compassion. Whereas, external factors included social support, income and family functionality. In regards to the importance of both internal and external factors, parents are expected to have better SWB in caring for their children with special needs.
\end{abstract}

Keywords: External and Internal Factors, SWB, Parents of Children With Special Needs.

\section{INTRODUCTION}

Research on subjective well-being (SWB) has been frequently carried out in this decade. However, SWB research on parents with special need children was still limited. Electronic data search done through Science Direct, Reserchgate, Sage, Garuda and Google Scholar only detected several SWB research done on parents who have children with special needs in Italy: Toffalini, E., Veltri, A., \& Cornoldi, C. (2015) [1]; in Israel: Shenaar-Golan, V. (2016) [2]; Shenaar - Golan, V. (2017) [3]; Werner, S., \& Shulman, C. (2013) [4]; in Ghana: Dey et al (2019) [5]; in America: King et al (2000) [6]; in Indonesia: Hasanah, N. (2019) [7]; Khoiriyah, N. M., Agustin, R. W., \& Setyanto, A. T. (2016) [8]; Malik, F. (2018) [9]; Murisal, M., \& Hasanah, T. (2017) [10]; Negeri, C. B. (2013); Nurlaela, Siti (2016) [11]; Pandin, D. A. M., Fitriana, E., Iskandarsyah, A., \& Siregar, J. (2019) [12]; Pertiwi, D. Y., \& Maryatmi, A. S. (2019) [13]; Ratnasari, R. D., \& Sumiati, N. T. (2018) [14]; Rinaldi, M. R., \& Retnowati, S. (2016) [15]; Shafanisa, A. T., Azizah, E., \& Victoria, E. E. (2017) [16]; in Pakistan: Fatima, I., \& Suhail, K. (2010) [17]; Fatima, I., \& Suhail, K. (2020) [18]; in
Taiwan: Hsieh, Y. L., \& Lo, J. L. (2013) [19]; in Turkey: Palanc1, M. (2018) [20]; in Iran: Rostami, M., Mehraban, S., Zarei, F., Sharifi, M., \& Movallali, G. (2019) [21]; in Malaysia: Ubeh, C., Bahari, F., \& Voo, P. S. K. (2017) [22].

SWB is a broad concept regarding the evaluation one's life and emotional experience which consists of high life satisfaction, high positive effect, and low negative effect. A person with strong SWB is able to regulate emotions and deal with problems. On the other hand, those with inadequate SWB tend to feel that their lives are unhappy, full of negative thoughts and feelings, causing anxiety, anger, and even the risk of depression [23]. SWB parents who have children with special needs should receive adequate recognition to help them enhance their SWB.

\section{METHOD}

The literature search was carried out using the Systematic Literature Review (SLR) in the form of PRISMA method. Currently, there is no research focusing on the external and internal SWB factors of parents who have children with special needs. The 
literature search was carried out on September 1 to 15 , 2020 throguh several electronic database namely Science Direct, Reserchgate, Sage, Garuda and Google Scholar. Electronic database was preferred for its indexes more research results in the social field, especially psychology. The search used the keywords "kesejahteraan subjektif" and "subjective well-being" of parents who have children with special needs.

The criteria set for the search were: 1) The research article discusses SWB of parents who have children with special needs; 2) The article discusses the effect of the variable " $\mathrm{X}$ " on the SWB of parents who have children with special needs; 3) The article contains a research report (original article); 4) Articles are written in English and Indonesian; 5) Data analysis is done using quantitative method; 6) The period of publication is limited from 2015 to 2019.
In this study, researchers identified, evaluated, and interpreted all relevant research results. The researcher obtained 25 published articles which were then sorted out, leaving only 16 published articles with strong relevancy. These research were summarized with detail information on: 1) The name of the researcher; 2) Year of publication; 3) Sample; 4) Measuring instrument used; 5) Purpose; 6) The country where the research was conducted; and 7) Research results. Nine irrelevant published articles were eliminated because: 1) Using qualitative methods; 2) The number of research subjects is not explained; 3) Research year older than 2015.

\section{RESULT}

The results of the systematic review on SWB parents of children with special needs are summarized in table 1 , table 2 and table 3.

Table 1. Internal factors

\begin{tabular}{|l|l|l|}
\hline No & Aspect & Reference \\
\hline 1. & Hope & $\begin{array}{l}\text { Shenaar-Golan, V. (2016) [2]; Shenaar-Golan, V. (2017) [3]; Ubeh, C., Bahari, F., \& Voo, P. } \\
\text { S. K. (2017) [22]. }\end{array}$ \\
\hline 2. & Gratitude & Murisal, M., \& Hasanah, T. (2017) [10]. \\
\hline 3. & Spiritual & $\begin{array}{l}\text { Ratnasari dan Sumiati, (2018) [14]; Dey et al., (2019) [5]; Ubeh, C., Bahari, F., \& Voo, P. S. } \\
\text { K. (2017) [22]. }\end{array}$ \\
\hline 4. & Emotion Control & Nurlaela, Siti (2016) [11]. \\
\hline 5. & Parenting self-efficacy & Hasanah, Mulyati, \& Tarma (2019) [7]. \\
\hline 6. & Resilience & $\begin{array}{l}\text { Dey et al (2019) [5]; Palanc1, M. (2018) [20]; Pandin, D. A. M., Fitriana, E., Iskandarsyah, } \\
\text { A., \& Siregar, J. (2019) [12]. }\end{array}$ \\
\hline 7. & Marital status & $\begin{array}{l}\text { Malik, F. (2018) [9]; Palanc1, M. (2018) [20]; Shenaar-Golan, V. (2016) [2]; Shenaar-Golan, } \\
\text { V. (2017) [3]. }\end{array}$ \\
\hline 8. & Self-Efficacy & Fatima, I., \& Suhail, K. (2020) [18]. \\
\hline 9. & Seft compassion & Ratnasari, R. D., \& Sumiati, N. T. (2018) [14]. \\
\hline 10. & Mindfull Parenting & Rinaldi, M. R., \& Retnowati, S. (2016) [15]. \\
\hline 11. & Parental Assessment & Shenaar-Golan, V. (2017) [3]; Toffalini, E., Veltri, A., \& Cornoldi, C. (2015) [1]. \\
\hline
\end{tabular}

Table 2. External factors

\begin{tabular}{|l|l|l|}
\hline No & Aspect & Reference \\
\hline 1. & Social support & $\begin{array}{l}\text { Pertiwi dan Maryatmi, (2019) [13]; Ratnasari dan Sumiati, (2018) [14]; Ubeh, C., } \\
\text { Bahari, F., \& Voo, P. S. K. (2017) [22]; Fatima, I., \& Suhail, K. (2020) [18]. }\end{array}$ \\
\hline 2. & Income & Ratnasari, R. D., \& Sumiati, N. T. (2018) [14]. \\
\hline 3. & Family Functionality & Shafanisa, A. T., Azizah, E., \& Victoria, E. E. (2017) [16]. \\
\hline
\end{tabular}


Table 3. General factors

\begin{tabular}{|c|c|c|}
\hline No & Aspect & Reference \\
\hline 1. & $\begin{array}{l}\text { Gender differences } \\
\mathbf{2 1 \%}\end{array}$ & $\begin{array}{l}\text { Fatima, I., \& Suhail, K. (2020) [18]; Hasanah, N. (2019) [7]; Khoiriyah, N. M., Agustin, R. W., \& } \\
\text { Setyanto, A. T. (2016) [8]; Pandin, D. A. M., Fitriana, E., Iskandarsyah, A., \& Siregar, J. (2019) } \\
\text { [12]; Rinaldi, M. R., \& Retnowati, S. (2016) [15]; Shafanisa, A. T., Azizah, E., \& Victoria, E. E. } \\
\text { (2017) [16]. }\end{array}$ \\
\hline 2. & $\begin{array}{l}\text { Purpose } \\
7 \%\end{array}$ & $\begin{array}{l}\text { Shenaar-Golan, V. (2016) [2]; Shenaar-Golan, V. (2017) [3]; Ubeh, C., Bahari, F., \& Voo, P. S. K. } \\
(2017) \text { [22]. }\end{array}$ \\
\hline 3. & $\begin{array}{l}\text { Religion and } \\
\text { Spirituality } \\
\mathbf{2 5 \%}\end{array}$ & $\begin{array}{l}\text { Dey et al., (2019) [5]; Khoiriyah, N. M., Agustin, R. W., \& Setyanto, A. T. (2016); Ratnasari, R. D., } \\
\text { \& Sumiati, N. T. (2018) [8]; Rinaldi, M. R., \& Retnowati, S. (2016) [15];Ubeh, C., Bahari, F., \& } \\
\text { Voo, P. S. K. (2017) [22]. }\end{array}$ \\
\hline 4. & $\begin{array}{l}\text { Quality of social } \\
\text { relationships } \\
\mathbf{3 6 \%}\end{array}$ & $\begin{array}{l}\text { Fatima, I., \& Suhail, K. (2020) [18]; Malik, F. (2018) [9]; Palanc1, M. (2018) [20]; Pandin, D. A. } \\
\text { M., Fitriana, E., Iskandarsyah, A., \& Siregar, J. (2019) [12]; Ratnasari, R. D., \& Sumiati, N. T. } \\
\text { (2018) [14]; Shafanisa, A. T., Azizah, E., \& Victoria, E. E. (2017) [16]; Shenaar-Golan, V. (2016) } \\
\text { [2]; Shenaar-Golan, V. (2017) [3]; Toffalini, E., Veltri, A., \& Cornoldi, C. (2015) [1]; Ubeh, C., } \\
\text { Bahari, F., \& Voo, P. S. K. (2017) [22]. }\end{array}$ \\
\hline 5. & $\begin{array}{l}\text { Personality } \\
11 \%\end{array}$ & $\begin{array}{l}\text { Hasanah, N. (2019) [7]; Ratnasari, R. D., \& Sumiati, N. T. (2018) [14]; Toffalini, E., Veltri, A., \& } \\
\text { Cornoldi, C. (2015) [1]. }\end{array}$ \\
\hline
\end{tabular}

\subsection{Discussion}

This study has identified that $36 \%$ of social relationship quality is developed from social support which is a major external factor affecting SWB to make parents feel valued, supported and loved (Fatima, I., \& Suhail, K. (2020) [18]; Malik, F. (2018) [9]; Palanc1, M. (2018) [20]; Pandin, D. A. M., Fitriana, E., Iskandarsyah, A., \& Siregar, J. (2019) [12]; Ratnasari, R. D., \& Sumiati, N. T. (2018) [14]; Shafanisa, A. T., Azizah, E., \& Victoria, E. E. (2017) [16]; ShenaarGolan, V. (2016) [2]; Shenaar-Golan, V. (2017) [3]; Toffalini, E., Veltri, A., \& Cornoldi, C. (2015) [1]; Ubeh, C., Bahari, F., \& Voo, P. S. K. (2017) [22]).

Religion and spirituality are internal factors that contributed $25 \%$ for parents who have children with special needs, one of which is through gratitude. Gratitude allows parents who have children with special needs to appreciate whatever they get in life for they believe it is a gift from God (Dey et al., (2019) [5]; Khoiriyah, N. M., Agustin, R. W., \& Setyanto, A. T. (2016); Ratnasari, R. D., \& Sumiati, N. T. (2018) [8]; Rinaldi, M. R., \& Retnowati, S. (2016) [15];Ubeh, C., Bahari, F., \& Voo, P. S. K. (2017) [22]).

Furthermore, internal factors that affect the special treatment of children from parents are religion and spirituality by $25 \%$, this is because religion is the basis of children's life. With an understanding of understanding of religion, children can become better individuals in society. (Dey et al., (2019) [5]; Khoiriyah, N. M., Agustin, R. W., \& Setyanto, A. T. (2016); Ratnasari, R. D., \& Sumiati, N. T. (2018) [8]; Rinaldi,
M. R., \& Retnowati, S. (2016) [15];Ubeh, C., Bahari, F., \& Voo, P. S. K. (2017) [22]).

Gender difference becomes the next internal factor. Knowledge about understanding gender differences for children is the next point that cannot be eliminated. Get the final result of $21 \%$ because it also affects children to respect differences, especially in the realm of gender. (Fatima, I., \& Suhail, K. (2020) [18]; Hasanah, N. (2019) [7]; Khoiriyah, N. M., Agustin, R. W., \& Setyanto, A. T. (2016) [8]; Pandin, D. A. M., Fitriana, E., Iskandarsyah, A., \& Siregar, J. (2019) [12]; Rinaldi, M. R., \& Retnowati, S. (2016) [15]; Shafanisa, A. T., Azizah, E., \& Victoria, E. E. (2017) [16])

The next internal factor is Personality as much as $11 \%$. Knowing yourself and other people's personalities is the most important thing in advancing children's development. Knowing about your potential, developing your talents and planning for the future. (Hasanah, N. (2019) [7]; Ratnasari, R. D., \& Sumiati, N. T. (2018) [14]; Toffalini, E., Veltri, A., \& Cornoldi, C. (2015) [1]).

Purpose is an internal factor in the special treatment of parents to children with the smallest percentage, which is $7 \%$. Even though it is an internal factor with the smallest percentage, it must also be a concern for parents to their children. A child from childhood must have goals for his future. Either short term or long term goals. (Shenaar-Golan, V. (2016) [2]; Shenaar-Golan, V. (2017) [3]; Ubeh, C., Bahari, F., \& Voo, P. S. K. (2017) [22].). 


\subsection{Conclusion}

Grouping the factors affecting SWB parents of children with special needs based on external and internal factors is expected to improve parents' awareness about this issue. Future researchers are encouraged to develop proper strategies in determining which internal and external factors that effectively improve the SWB of parents who have children with special needs.

\section{REFERENCES}

[1] E. Toffalini, A. Veltri, and C. Cornoldi, 'Metacognitive aspects influence subjective wellbeing in parents of children with cancer: Metacognitions influence well-being in parents of children with cancer', Psycho-Oncology, vol. 24, no. 2, pp. 175-180, Feb. 2015, doi: 10.1002/pon.3622.

[2] V. Shenaar-Golan, 'The Subjective Well-Being of Parents of Children with Developmental Disabilities: The Role of Hope as Predictor and Fosterer of Well-Being', Journal of Social Work in Disability \& Rehabilitation, vol. 15, no. 2, pp. 77-95, Apr. 2016, doi: 10.1080/1536710X.2016.1162119.

[3] V. Shenaar-Golan, 'Hope and subjective wellbeing among parents of children with special needs: Parents of children with special needs', Child \& Family Social Work, vol. 22, no. 1, pp. 306-316, Feb. 2017, doi: 10.1111/cfs.12241.

[4] S. Werner and C. Shulman, 'Subjective wellbeing among family caregivers of individuals with developmental disabilities: The role of affiliate stigma and psychosocial moderating variables', Research in Developmental Disabilities, vol. 34, no. 11, pp. 4103-4114, Nov. 2013, doi: 10.1016/j.ridd.2013.08.029.

[5] N. E. Y. Dey, B. Amponsah, and C. B. WiafeAkenteng, 'Spirituality and subjective well-being of Ghanaian parents of children with special needs: The mediating role of resilience', $J$ Health Psychol, p. 135910531987395, Sep. 2019, doi: 10.1177/1359105319873956.

[6] L. A. King, C. K. Scollon, C. Ramsey, and T. Williams, 'Stories of Life Transition: Subjective Well-Being and Ego Development in Parents of Children with Down Syndrome', Journal of Research in Personality, vol. 34, no. 4, pp. 509536, 2000, doi: https://doi.org/10.1006/jrpe.2000.2285.

[7] N. Hasanah, Mulyati, and Tarma, 'Hubungan Parenting Self-Efficacy Dengan Subjective WellBeing Pada Ibu yang Memiliki Anak Berkebutuhan Khusus', JKKP, vol. 6, no. 02, pp. 103-108, Oct. 2019, doi: 10.21009/JKKP.062.04.

[8] N. M. Khoiriyah, R. W. Agustin, and A. T. Setyanto, 'Pengaruh Pelatihan Syukur terhadap Peningkatan Subjective Well Being pada Ibu yang
Memiliki Anak Down Syndrome', Wacana, vol. 8, no. 1, pp. 1-13, 2016.

[9] F. Malik, 'Hubungan Kesejahteraan Subjektif dan Resolusi Konflik Terhadap Kepuasan Pernikahan Orang Tua yang Memiliki Anak Autis', Psikoborneo, vol. 6, no. 1, pp. 36-42, 2018.

[10] Murisal and T. Hasanah, 'Hubungan Bersyukur dengan Kesejahteraan Subjektif pada Orang Tua yang Memiliki Anak Tunagrahita di SLB Negeri 2 Kota Padang', KONSELI: Jurnal Bimbingan dan Konseling, vol. 4, no. 2, pp. 81-88, 2017.

[11] S. Nurlaela, 'Pengaruh Pelatihan Regulasi Emosi untuk Meningkatkan Subjective Well-Being pada Orangtua dengan Anak Berkebutuhan Khusus (ABK)', PSIKOPEDAGOGIA, vol. 5, no. 2, pp. 109-116, Dec. 2016, doi: 10.12928/psikopedagogia.v5i2.7112.

[12] D. A. M. Pandin, E. Fitriana, A. Iskandarsyah, and J. Siregar, 'Comparison of Resilience and Subjective Well-being to Fathers and Mothers Who Have Postlingual Deafness Children', JKP, vol. 7, no. 3, pp. 81-95, Dec. 2019, doi: 10.29210/134600.

[13] D. Y. Pertiwi and A. S. Maryatmi, 'Gambaran Subjective Well Being Pada Ibu yang Memiliki Anak Thalasemia di Perumahan X', IKRAITHHUMANIORA, vol. 3, no. 1, pp. 118-27, 2019.

[14] R. D. Ratnasari and N. T. Sumiati, 'Pengaruh Self-Compassion, Religiusitas, Support Group Dan Pendapatan Terhadap Subjective Well-Being Orang Tua Anak Tunagrahita', Jurnal Pengukuran Psikologi dan Pendidikan Indonesia (JP3I), vol. 6, no. 1, pp. 63-78, Jun. 2018, doi: 10.15408/jp3i.v6i1.8153.

[15] M. R. Rinaldi and S. Retnowati, 'Program "Mindful Parenting" untuk Meningkatkan Kesejahteraan Subjektif Ibu yang Memiliki Anak Retardasi Mental', gamajpp, vol. 2, no. 2, pp. 100-115, Aug. 2016, doi: 10.22146/gamajpp.33362.

[16] A. T. Shafanisa, E. Azizah, and E. E. Victoria 'Hubungan antara Dimensi Fungsionalitas Keluarga dan Subjective Well-Being (SWB) pada Ibu yang Memiliki Anak Disabilitas Intelektual di SLB - C Bandung', Humanitas, vol. 1, no. 1, pp. 1-10, Jul. 2017, doi: 10.28932/humanitas.v1i1.398.

[17] I. Fatima and K. Suhail, 'Belief in a just world and subjective well-being: Mothers of normal and Down syndrome children', International Journal of Psychology, vol. 45, no. 6, pp. 461-468, Dec. 2010, doi: 10.1080/00207591003774519.

[18] I. Fatima and K. Suhail, 'Protective Factors for Subjective Well-being in Mothers of Children with Down Syndrome', PJPR, vol. 34, no. 4, pp. 655-669, Jan. 2020, doi: 10.33824/PJPR.2019.34.4.36.

[19] Y.-L. Hsieh and J.-L. Lo, 'Occupational Experiences and Subjective Well-being of Mothers of Children with ASD in Taiwan: 
Occupational Experiences and Subjective Wellbeing', Occup. Ther. Int., vol. 20, no. 1, pp. 4553, Mar. 2013, doi: 10.1002/oti.1339.

[20] M. Palanc1, 'The Prediction of Family Resilience, Subjective Well-being and Marital Adjustment of Parents Who Has a Child with a Disability by Psychosocial Competencies', EB, vol. 43, no. 193, pp. 217-236, Apr. 2017, doi: 10.15390/EB.2017.4384.

[21] M. Rostami, S. Mehraban, F. Zarei, M. Sharifi, and G. Movallali, 'Subjective Wellbeing and Interpersonal Problems in the Mothers of Students With Learning Disabilities', Iran. Rehabil. J., pp. 207-214, Sep. 2019, doi: 10.32598/irj.17.3.207.

[22] C. Ubeh, F. Bahari, and P. V. S. Kiong, 'Kesejahteraan Subjektif Ibu Bapa Kanak-Kanak Kurang Upaya Pembelajaran: Pengaruh Komitmen Keagamaan, Harapan Terhadap Anak, Dan Sokongan Sosial', Jurnal Psikologi Malaysia, vol. 31, no. 2, pp. 45-56, 2017.

[23] E. Diener, S. Oishi, and R. E. Lucas, 'National accounts of subjective well-being.', American Psychologist, vol. 70, no. 3, pp. 234-242, 2015, doi: $10.1037 / \mathrm{a} 0038899$. 